Journal of Environmental Science and Public Health

doi: $10.26502 /$ jesph. 96120026

Volume 2, Issue 1

Research Article

\title{
Comparative Study of Habits in Scholar Students before and During His University Studies in Spain
}

\author{
Iglesias $\mathbf{M T}^{1 *}$, Cuesta $\mathbf{E}^{2}$
}

${ }^{1}$ Universidad Francisco de Vitoria, Ctra Pozuelo-Majadahonda, Pozuelo de Alarcón, Madrid, Spain

${ }^{2}$ Centro de Salud Colmenar de Oreja, Madrid, Spain

"Corresponding Author: Iglesias MT, Universidad Francisco de Vitoria, Ctra Pozuelo-Majadahonda, Pozuelo de Alarcón, Madrid, Spain, Tel: +34917091400; E-mail: m.iglesias.prof@ufv.es

Received: 09 November 2017; Accepted: 29 November 2017; Published: 02 January 2018

\begin{abstract}
Evidence suggests that in most Western countries young people adopt lifestyles that affect their health negatively, raising in this way the risk of the premature appearance of chronic illnesses.

Objective: is to compare the habits of scholar and university students in Madrid, Spain.

Material and methods: longitudinal study with students from some universities and schools in Madrid, Spain. Participatin 1600 students of both sexes, pre-university and university level, agreed to participate in the study: 653 men (41.3\%) and 940 women (58.7\%). The students were classified into 2 age groups: $\leq 17$ years old (scholar) and $\geq 18$ years old (university).

Results: The BMI, the physical activity and the negative habits in terms of consumption of food stuffs and alcohol were studied. Most of them are of normal weight (80\%), and with regard to physical activity, the study found the scholar students to be the most active.

Conclusion: Differences were found between the sexes, which finding should guide actions of intervention with relation to physical activity or habits, and so it seems to be fundamental to carry out programmes of nutritional and psychosocial intervention in adolescents and young people, to prevent and to reduce the consumption of alcohol.
\end{abstract}

Keywords: Habits; Scholar students; University students; Spain 


\section{Introduction}

The prevalence of excessive weight, and the fact that obesity has tripled over the last twenty years, has become a challenge recognised by the World Health Organisation (WHO), which has classified it as a global epidemic [1]. The diet of young people can usually be characterised by excessive consumption of meats and their derivatives, as well as refined sugars, while the consumption of fish, fruit and vegetables is deficient, which gives rise to an imbalance in the percentage contributions of the direct sources of the daily calorific intake [2-4]. This decline in the quality of the diet will have future repercussions for their health. For this reason, over recent years, health policies have been directed at getting the populace to improve the quality of its food intake, promoting healthy habits such as reducing the consumption of saturated fats, carbohydrates and refined sugars and increasing the intake of fruit, vegetables and fish [1], set in the context of the Mediterranean diet.

Nutrition, together with appropriate physical activity, represents the most important contributors to enjoying good health. The young part of the population appears to be more vulnerable, in relation with its dietary habits, to the effects of globalisation, while with regard to the university community this is compounded by the assumption of new responsibilities (preparation of menus, purchasing food) and the irregularity in the hours kept $[5,6]$. In Spain, the diet of the university population can be characterised as rich in proteins, cholesterol and saturated fats $[2,7,8]$. Despite this, university students are aware of the importance of eating properly for their health, although this stage of education makes doing so difficult due to the lack of time for it [9].

With respect to the adolescent population (14-17 years old), despite taking their main meals at home, these also comprise a group at nutritional risk, and while girls generally display better habits, they are also a vulnerable group from the perspective of nutritional risk $[10,11]$. One of the problems to be found in modern society is the easy access by young people to foods made up to a great extent of empty calories and fast food [12]. There is not a great deal of information about the self-reported data of young people [13], while there is for the adult population. Excessive weight, and above all obesity, is related with the early appearance of chronic illnesses, a reduction in quality of life and a rise in healthcare expenditure. The prevalence of both in children and adolescents has risen over recent decades, especially in some autonomous regions of Spain [14]. This is contributed to by the fall in practising physical activity and in the case of Spain, the rise in obesity makes a review of the lifestyle of young people necessary [15].

In most Western countries young people adopt lifestyles that affect their health negatively, raising in this way the risk of the premature appearance of chronic illnesses, partly brought about by deficient eating habits and sedentary lifestyles with little physical activity, all of which is difficult to modify when adulthood is reached [16,17]. Another problem is the high consumption of alcohol by adolescents and young people. The consumption of alcohol among adolescents gives rise to a potential risk of suffering neuro-degenerative processes (principally, lesions in regions of the brain implicated in learning and memory) and disorders in brain activity which will have effects in adulthood 
[18]. Because of all this, the objective of the present study was to compare the patterns of habits of scholars and university students in the western zone of Madrid, Spain.

\section{Material and Methods}

Longitudinal and descriptive study, in which the participants are students in Madrid, of a similar socioeconomic level, chosen randomly in Madrid universities, and secondary schools of Madrid, Spain. No foreign students participated in the study. The object of the study was explained to those in charge of the school centres, the students were asked to give informed consent, and 1600 students of both sexes are invited to participate and agreed to collaborate in the study, the number of women being higher than that of men, which fact could not be modified as women predominated in the centres where the study was performed. One limitation of the study is that the socioeconomic scope is not variable, and the number of participants in the same.

A questionnaire was presented, completed in the presence of the interviewer, which included questions on anthropometric data, physical activity, dietary habits (breakfast, type of snack, number of meals per day, frequency of consumption of foods) and consumption of alcohol. For each interviewee, the self-reported anthropometric data of weight and height, whose reliability might be a limitation, were recorded in the distribution of students by their body mass index (BMI); in turn they were distributed pursuant to the classification criteria proposed by the SEEDO (Spanish Society for the Study of Obesity) [19]. The weight and height data, for calculating the body mass index (BMI) were furnished by the students themselves, and of all those studied, only the data of 1490 students of both sexes were valid. The BMI was calculated with the values used normally $\left(<20,20-24,25-29\right.$ or $\left.>30 \mathrm{~kg} / \mathrm{m}^{2}\right)$. So as to enable analysis of whether or not there were discrepancies between the self-reported data and those measured, for a pilot group (data not shown), it was checked whether the data provided by this group were different from the values measured by specialised personnel [20]. With regard to physical activity, in the questionnaire they filled in, respondents were asked whether they undertook any daily, weekly or monthly sports activity, whether they walked for at least 30 minutes, whether they used public or private transport, whether they used lifts or escalators instead of the stairs. Similarly, they were asked about sedentary activities (time in front of the TV, computer, video games). To assess the consumption of alcoholic drinks, they were asked about the type of drink taken (wine, beer, high ABV), frequency of the same (occasional, frequent, daily), and to appraise the risk of this consumption, the AUDIT Questionnaire [13] was employed. 1600 students men and women, scholars and university level, agreed to participate in the study: 660 men $(41.3 \%)$ and 940 women $(58.7 \%)$. All of them provided consent to participate in the study.

To facilitate the study, the sample population was divided on the basis of age, yielding 2 groups: one of ages $\leq 17$ (66.3\%) representing scholars students $(\mathrm{n}=1050)$ and another group of ages $\geq 18(34.7 \%)$, made up of university students $(\mathrm{n}=550)$. 
When we evaluated the data on physical activity in the surveys carried out, we only obtained valid results for 1490 students $(93.1 \%$ of the total sample). From the questionnaire used to reveal both the dietary habits, as well as the consumption of alcohol, physical activity and sleep, of the students, of all the students surveyed, only the responses received from 1530 students were valid. To simplify the study of physical habits, 5 negative traits were looked for in the students (when they answered that they hardly did any daily physical activity, that they walked for less than 30 minutes/day, when they had to move around they always used a car or other means of transport, they always used the lift instead of going up the stairs), where a score of 0 was assigned to a good habit and 5 to a poor one.

With respect of dietary habits, 25 different habits specific to eating were assessed, combined into a single variable which accounted for good, poor and normal habits. We considered both regularity and poor habits: for instance, a single meal per day, not eating breakfast, eating precooked foods frequently, eating a lot of industrial bakeries, eating only 1 piece of fruit 3-4 times/week, high consumption of meat so as to exclude fish and extensive use of fats such as butter or margarine instead of olive oil.

The study was concluded with the habits of alcohol consumption, and 6 different behaviours were assessed, highlighting the consumption of those whose alcohol intake is high, either in total or frequency, both for low-ABV drinks (wine, beer), and high-ABV drinks (rum, vodka, etc.). The consumption data for both were furnished by the participants. We also considered as negative habits the number of drinks of different strengths taken in the course of the weekend, from Thursday to Saturday.

Prior to the analyses, all variables were checked for normal distribution. The chi-squared test was used to draw comparisons between the age and gender groups for the categorical or categorised variables. To compare the averages of the quantitative variables with respect to age and sex, two-factor analysis of variance (Anova) was carried out. The Student's t-test was used when it was necessary to compare two means and the relationship between two quantitative variables was measured using the Pearson correlation coefficient.

\section{Results and Discussion}

The questionnaire was given to students from preuniversity and university students in Madrid, from public and private centres. The lifestyle of young people currently shows a tendency to display patterns which it will be necessary to study in greater depth to identify possible future disorders such as obesity. Young people often give the impression that they know everything, although when it comes to nutritional and life habits there is a great lack of awareness, and prevention is crucial in this field to head off the future repercussions, both in health and socioeconomic terms.

The self-reported and categorised BMI of the participants of both sexes was: $12.4 \%$ underweight, $79.2 \%$ normal weight and $8.4 \%$ overweight or obese. Normal weight predominated in the student population of both sexes, with underweight slightly more prevalent in the females, though without significant differences. Significant differences 
were observed between the age groups, both in men $(\mathrm{p}=0.045)$, and in women $(\mathrm{p}<0.001)$ with the pre-university female students being underweight more frequently, in a much higher percentage than for their university counterparts. If we compare the two population groups overall, $15.5 \%$ of the scholar students are underweight, compared with $6.7 \%$ for the other group $(\mathrm{p}<0.001)$. With respect to overweight-obesity the percentages are similar, at $7.9 \%$ and $9.3 \%$. In the men, there were no significant differences in BMI with respect to age, $\mathrm{p}=0.605$. For the women, a large difference in BMI was observed, $\mathrm{p}<0.001$. In the case of underweight, the vulnerable students are those of scholar age of both sexes, and it is necessary to pay special attention to the possible risk of eating disorders, of special concern in the case of women.

In the two-factor Anova using the uncategorised BMI, the differences between the sexes are significant ( $\mathrm{p}=0.002)$, just as they are for age $(\mathrm{p}=0.008)$. Although the graph (Figure 1) shows a greater rise with age in women than in men, the sex-age interaction does not reach the level of significance $(\mathrm{p}=0.110)$.

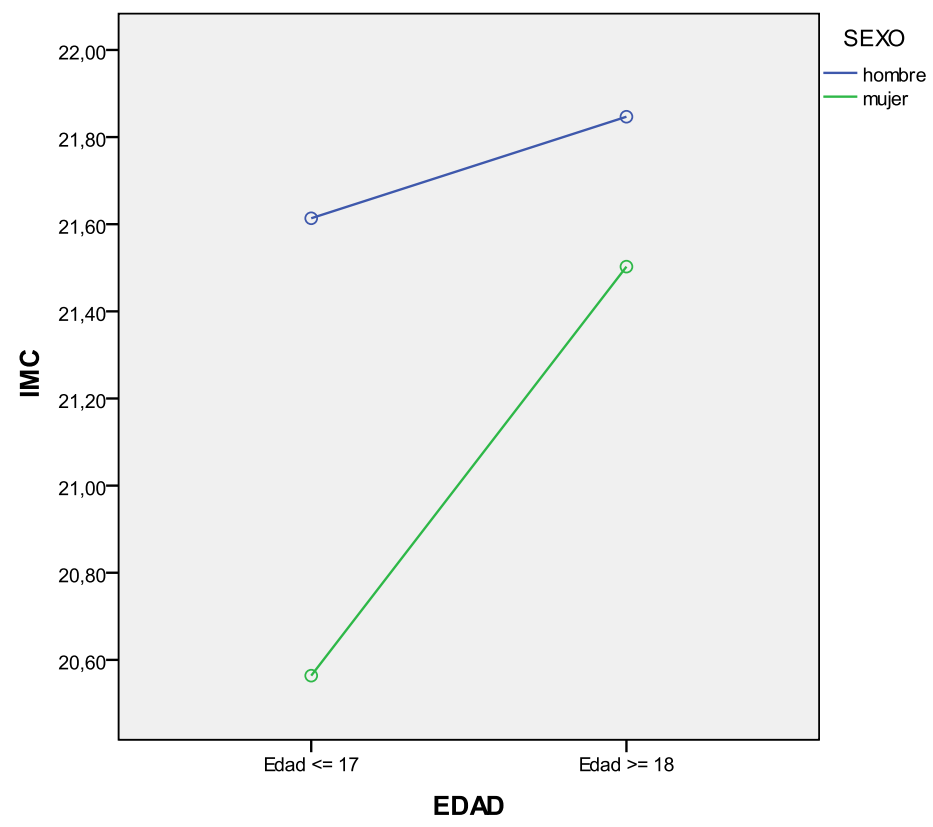

Figure 1: Anova of BMI (IMC), sex (hombre=man; mujer=women) and age (=edad; $\leq 17$ years and $\geq 18$ years).

The notable rise in overweight and obesity in the young populace is turning into a health problem at a national level. Even though the anthropometric study might suffer from a limitation because the weight and height are selfreported, so that the real values might have been lower or higher, we have seen that these values do serve for assessing the nutritional condition. The values obtained were compared with those of a pilot sample (unpublished data), and it was seen that the differences are very minor, even though generally both sexes tend to underestimate their weight, while the contrary happens with their stature [20]. The absence of significant differences has also been seen in Bes-Rastrollo et al. [21]. 
With respect to the physical activity (Table 1), the differences observed are highly significant ( $<<0.001$ ), the scholar men being the most active, $40 \%$, while this percentage drops to $6.8 \%$ in university women. With regard to physical habits, in our sample, the differences in the age groups are not significant $(\mathrm{p}=0.651)$, although among women the university age group is more sedentary than the scholar $(\mathrm{p}=0.067)$.

The negative habits in relation to physical activity arise from their sedentary nature: they hardly use the stairs, but frequently take the lift, they hardly travel on foot on a daily basis (they do not walk for at least 30 minutes), and they state that they do not engage in physical activity either indoors or outdoors on a more or less regular basis. In Table 1 , the habits and the kind of physical exercise engaged in are compared as a function of age in both sexes. Now, if we compare the averages in the age groups using the Student's t-test for the two sexes separately, the negative physical activity habits of men do not show significant differences $(\mathrm{p}=0.311)$, while the differences were significant in the women $(\mathrm{p}=0.002)$. In the two-factor Anova for uncategorised physical habits, there are significant global differences on the basis of age ( $\mathrm{p}=0.009)$, though not when we compare the two sexes $(\mathrm{p}=0.178)$, nor in the sex-age interaction $(\mathrm{p}=0.306)$. The change with age is similar for the two sexes, as can be seen in Figure 2, where the two straight lines are almost parallel.

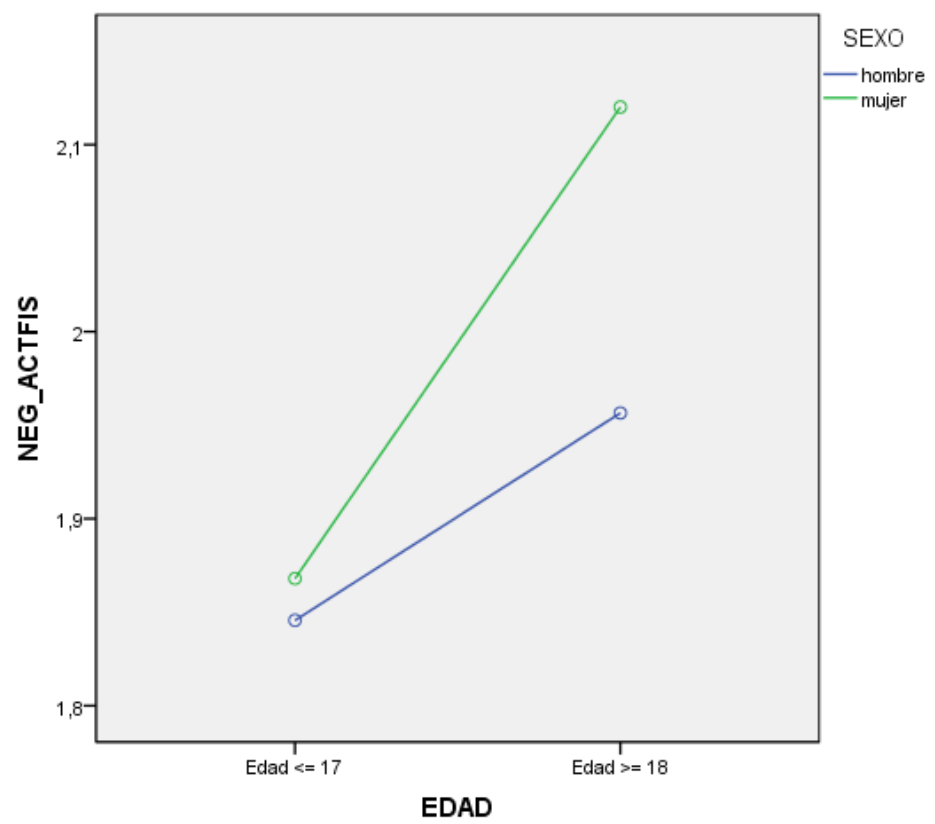

Figure 2: Anova of negative physical habits sex (hombre=man; mujer=women) and age (=edad; $\leq 17$ years and $\geq 18$ years). 


\begin{tabular}{|c|c|c|c|}
\hline \multirow{2}{*}{ Physical Activity } & \multicolumn{2}{c|}{ Age } \\
\cline { 2 - 4 } & $\leq 17$ & $\geq 18$ \\
\hline \multirow{3}{*}{ Habits } & Good & $38.4 \%$ & $35.3 \%$ \\
\cline { 2 - 4 } & Normal & $33.7 \%$ & $30.3 \%$ \\
\cline { 2 - 4 } & Poor & $27.9 \%$ & $34.4 \%$ \\
\hline \multirow{3}{*}{ Type } & Slight & $27.5 \%$ & $61.4 \%$ \\
\cline { 2 - 4 } & Moderate & $42.7 \%$ & $26.5 \%$ \\
\cline { 2 - 4 } & High & $29.8 \%$ & $12.1 \%$ \\
\hline
\end{tabular}

Table 1: Comparative study of habits and type of physical activity in pre-university and university students of both sexes.

Physical activity, just like eating, impinges on people's health. Physical inactivity is a determinant of health, and in the case of our population, who live in an urban environment, and with little incentive to engage in physical exercise or frequent use of public transport, this means that it becomes a risk factor [22]. A physically active lifestyle is generally associated with healthier habits and a lower incidence of habits inappropriate to health such as the consumption of alcohol [23].

We are currently faced with a potentially obesogenic environment, because of the decline in physical activity and the establishment of a fairly sedentary lifestyle. In the HELENA study, it was indicated that 60 minutes/day of moderate and vigorous physical activity is associated with a reduction of the risk of overweight-obesity in adolescents [24].

The possible bias due to using self-reported data of physical activity should be highlighted. If we take into account the age of the participants, the scholar group is seen to be more active, as reflected in González-Jiménez et al. [25]. In both age groups, the male sex is seen to be more active, in agreement with other studies [26, 27].

The dietary habits we label negative here arise from the fact that the population studied has fewer than 2 meals per day and does not regularly eat breakfast. With regard to foodstuffs consumed, participants refer to frequent consumption of precooked food, industrial bakeries, packaged juices, sweets and sugary drinks, while on the contrary the consumption of fresh vegetables, fruit, pulses and fish is deficient. When we compare the eating habits in the students of the study, as can be seen in Table 2, that in general these are normal in both populations, while in relation to good habits, women seem to adhere to them better than men. The habits of the age groups in males show 
significant differences. University students display better habits, especially among the women, with significant differences with respect to the younger group.

\begin{tabular}{|c|c|c|c|c|c|}
\hline \multirow{2}{*}{$\begin{array}{c}\text { SEX } \\
(\mathrm{p}<0.001)\end{array}$} & \multirow{2}{*}{ AGE } & & \multicolumn{3}{|c|}{ Eating Habits } \\
\cline { 4 - 6 } & & & Good \% & Normal \% & Poor \% \\
\hline \multirow{2}{*}{ MEN } & \multirow{2}{*}{$(\mathrm{p}=0.002)$} & $\leq 17$ & 16.3 & 49.5 & 34.2 \\
\cline { 3 - 6 } & $\geq 18$ & 29.2 & 38.0 & 32.8 \\
\hline \multirow{2}{*}{ WOMEN } & \multirow{2}{*}{$(\mathrm{p}=0.060)$} & $\leq 17$ & 26.8 & 48.4 & 24.8 \\
\cline { 3 - 6 } & & $\geq 18$ & 34.0 & 41.3 & 24.7 \\
\hline
\end{tabular}

Table 2: Dietary habits by sex and age.

In the two-factor Anova of uncategorised harmful dietary habits, we see (Figure 3) a clear and significant difference between the sexes $(\mathrm{p}<0.001)$, and to a lesser degree between the age groups $(\mathrm{p}=0.023)$. This being said, no significant sex-age interaction is found $(\mathrm{p}=0.787)$. This is the stage at which young people start with hypocaloric diets, which fact, combined with the acquisition of incorrect habits, is damaging to health in the more or less distant future. It is therefore important to detect possible subclinical deficiencies [28]. One fact to be highlighted is that in the university population, no differences are observed between those reading health sciences and those reading social sciences.

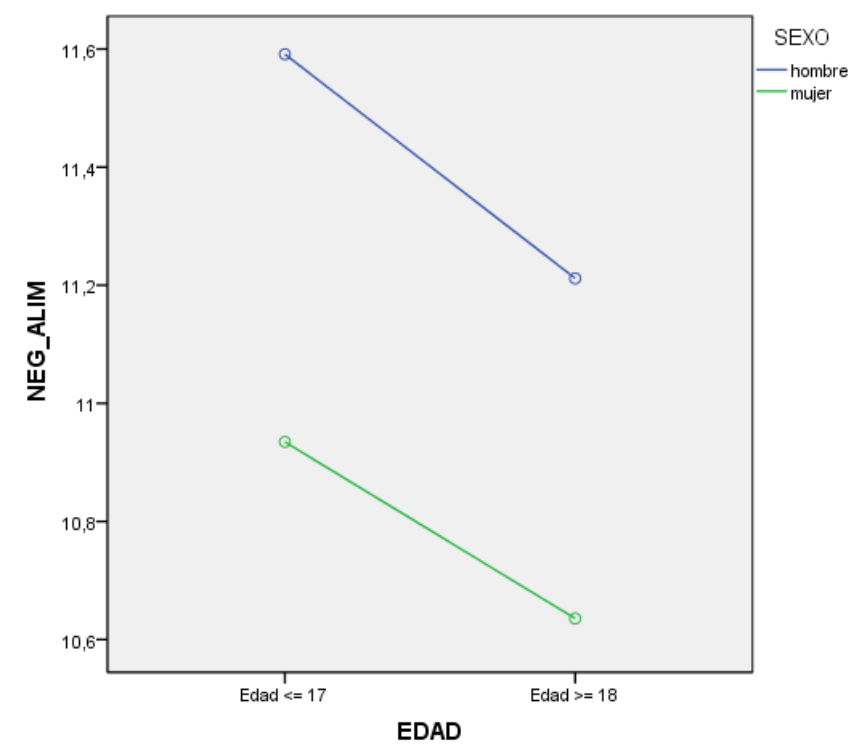

Figure 3: Anova of potentially harmful food consumption sex (hombre=man; mujer=women) and age (=edad; $\leq 17$ years and $\geq 18$ years). 
The adolescents have unconventional habits; they often skip meals, one of which is breakfast, with the consequent dietary imbalance in terms of lower intake of vitamins and minerals [26], so that reinforcing the interventions directed at this age group would have positive effects.

With respect to the consumption of alcohol in the population studied, we centred on those who consume it frequently. Thus, $9.2 \%$ have a poor habit and $17.9 \%$ a normal habit (unpublished data) when they are asked about their consumption of low-ABV and high-ABV drinks during the week and at weekends. In Table 3, the frequency of alcohol consumption in men is shown, where the regular-poor habits are higher in the university age group of both sexes. This being said, among the youngest, poor alcohol consumption habits are twice as prevalent in boys as in girls. Negative consumption relates here to the intake of more than 3 fermented drinks and more than 3 distilled drinks, as well as excessive consumption of alcohol at weekends. With respect to the habit of taking alcohol frequently, significant differences between the sexes are observed $(\mathrm{p}=0.006)$. According to ESTUDES, the consumption of alcohol among young people and the frequency of getting drunk are rising; there is also a pattern of increasing intensive consumption by young women [28].

\begin{tabular}{|c|c|c|c|c|c|}
\hline \multirow{2}{*}{$\begin{array}{c}\text { SEX } \\
(\mathrm{p}=0.006)\end{array}$} & \multirow{2}{*}{ AGE } & & \multicolumn{3}{|c|}{ Frequency of alcohol consumption } \\
\cline { 3 - 6 } & & & Good \% & Normal \% & Poor \% \\
\hline \multirow{2}{*}{ MEN } & \multirow{2}{*}{$(\mathrm{p}=0.090)$} & $\leq 17$ & 74.0 & 15.1 & 10.9 \\
\cline { 3 - 6 } & & $\geq 18$ & 64.4 & 20.0 & 15.6 \\
\hline \multirow{2}{*}{ WOMEN } & \multirow{2}{*}{$(\mathrm{p}=0.032)$} & $\leq 17$ & 76.4 & 18.0 & 5.6 \\
\cline { 3 - 6 } & & $\geq 18$ & 69.7 & 20.7 & 9.6 \\
\hline
\end{tabular}

Table 3: Frequency of alcohol consumption by sex and age.

In the two-factor Anova, with uncategorised frequency of alcohol consumption, significant differences are observed by $\operatorname{sex}(\mathrm{p}=0.001)$ and by age $(\mathrm{p}=0.001)$, while the interaction is not significant $(\mathrm{p}=0.816)$. No significant relationships are observed with respect to the consumption of fermented alcoholic drinks, when we relate BMI and age. In women (unpublished data), it was observed that the consumption of fermented drinks is significantly greater in the scholar group who are underweight $(11.1 \%)$ than in the elder group (4.4\%). With regard to excessive consumption of alcohol at weekends, the overweight-obesity group and $\geq 18$ years old reports the highest consumption, while those underweight and $\leq 17$ years old state their consumption is higher (unpublished data). A limitation of our study was the inability to analyse the types of alcohol in both groups, since such information was not available.

The habitual intake of alcohol in toxic doses by adolescents is associated with damage to the brain and intellectual development, which situation may affect them during adulthood [23]. The consumption of alcoholic drinks may alter the nutritional condition of young people by giving rise to modification in their eating habits, which, combined with 
the rise in the need for certain nutrients, may lead to a variety of nutritional deficiencies in a certain number of cases, due to circumstances of poor absorption [26].

\section{Conclusions}

The results observed in relation to the self-reported BMI even though the source entails a limitation, but following partly the methodology employed by Savane et al. [20], do seem to be applicable in the young adult population. Differences between the sexes have been found, which ought to guide actions of intervention in relation to physical activity or habits. The implementation of public health strategies aimed at adaptation to a healthy diet seems to be vital, as is the possibility of carrying out programmes of nutritional and psychosocial intervention with adolescents and young people so as to prevent and/or reduce the consumption of alcohol (in amounts which lead to toxicity or dependence) in the population. Finally, we should be cautious, as we cannot generalise our results for comparison with studies covering varied socioeconomic strata, given that the zone where the study was carried out is of middle to high status. Nevertheless, more longitudinal and experimental studies should be conducted to better understand sedentary behaviours and dietary habits.

\section{Acknowledgements}

The authors would like to express our gratitude to Dr. Pedro Cuesta for his invaluable help throughout the statistical study. This research has been funded by the Universidad Francisco de Vitoria, Spain. None of the other authors has any conflict of interest.

\section{References}

1. Branca F, Nikogosian H, Lobstein T. The Challenge of Obesity in the WHO European region and the Strategies for Response, EURO, 2007.

2. Bollat MP, Durá Travé T. Modelo dietético de los universitarios. Nutr. Hosp 23 (2008): 626-627.

3. Fernández I, Aguilar MV, Mateos CJ, et al. Hábitos alimentarios en una población juvenil de Guadalajara (Castilla La Mancha). Factores que influyen sobre la elección de alimentos. Rev. Esp. Nutr. Comunitaria 12 (2006): 172-181.

4. Iglesias T, Novak V, Elmadfa I. Nutritional assessment and dietary habits in nursing students from Spain. $19^{\text {th }}$ International Congress of Nutrition, Bangkok, Thailand. Ann. Nutr. Metab (2009): 348-349.

5. Durá-Travé T, Castroviejo A. Adherencia a la dieta mediterránea en la población universitaria. Nutr. Hosp 26 (2011): 602-608.

6. Martínez-Roldán C, Vaiga O, López de Andrés A, et al. Evaluación del estado nutricional de un grupo de estudiantes universitarios mediante parámetros dietéticos y de composición corporal. Nutr. Hosp 20 (2005): 197-203.

7. Iglesias López MT, Escudero E. Evaluación nutricional en estudiantes de enfermería. Nutr. Clin. Dietec. Hosp 30 (2010): 21-26. 
8. Iglesias López MT, Escudero E, Pérez A. Influyen los hábitos de vida y la ingesta dietética en los parámetros plasmáticos de nuestros universitarios? En VII Encuentro de Expertos en Salud Universitaria. Promoción de la salud. Madrid, UFV (2011): 39-49.

9. Serra Majem L, Ribas Barba L, Pérez Rodrigo C, et al. Nutrient adequacy in Spanish children and adolescents. Br. J. Nutr 1 (2006): S49-S57.

10. Fernández Morales I, Aguilar Vilas MV, Mateos Vega CJ, et al. Ingesta de nutrientes en una población juvenil, prevalencia de sobrepeso y obesidad. Nutr. Clin. Diet. Hosp 27 (2007): 148-159.

11. Serra Majem L, Aranceta Bartrina J, Pérez Rodrigo C, et al. Prevalence and determinants of obesity in Spanish children and young people. Br. J. Nutr 1 (2006): S76-S72.

12. Hidalgo MI, Montón JL, Güemes M. alimentación durante la adolescencia. En: Muñoz Calvo MT, Hidalgo Vicario MI, Clemente Pollán J. (eds.). Pediatría extra hospitalaria. Fundamentos clínicos para atención primaria. Madrid, Ergon (2008): 125-136.

13. Babor T, Higgins-Biddle J, Sanders J, et al. Cuestionario de Identificación de los Trastornos debidos al Consumo de Alcohol (AUDIT). Pautas para su utilización en Atención Primaria. OMS: Departamento de Salud Mental y Dependencia de Sustancias (2001).

14. Savane FS, Navarrete-Muñoz EA, García de la Hera M, et al. Validez del peso y talla autoreferido en población universitaria y factores asociados a las discrepancias entre valores declarados y medidos. Nutr. Hosp 28 (2013): 1633-1638.

15. Serra Majem L, Ribas L, Aranceta J. Epidemiología de la obesidad en España. Resultados del estudio Enkid (1998-2000). En obesidad infantil y juvenil. Estudio enkid. L Serra, J Aranceta (eds.) Masson, Barcelona (2001): 81-108.

16. Koplan JP, Liverman CT, Kraak VA. Committee of prevention of Obesity in children and youth. In Preventing childhood obesity: health in the balance, 2005. National Academies, Washington, D.C (2005).

17. Lobstein T, Freilut ML. Prevalence of overweight among children in Europe. Obes. Rev. 2003, 4: 195-200.

18. García Rivas F, Giménez Martínez R, García Burgos D. Efectos neurológicos del consumo de alcohol en adolescentes. Nutr.Hosp 20 (2005).

19. Rodríguez RF, Palma LX, Romo BA, et al. Hábitos alimentarios, actividad física y nivel socioeconómico en estudiantes universitarios de Chile. Nutr. Hosp 28 (2013): 447-455.

20. Rubio MA, Salas-Salvadó J, Barbany M, et al. Consenso SEEDO 2007 para la evaluación del sobrepeso y la obesidad y el establecimiento de criterios de intervención terapéutica. Rev. Esp. Obes 5 (2007): 135-175.

21. Bes-Rastrollo M, Pérez Valdivieso JR, Sánchez-Villegas A, et al. Validación del peso e índice de masa corporal autodeclarados de los participantes de una cohorte de graduados universitarios. Rev. Esp. Obes (2005): 352-358.

22. Durán S, Bazaez G, Figueroa K, et al. Comparación en calidad de vida y estado nutricional entre alumnos de nutrición y dietética y de otras carreras universitarias de la universidad Santo Tomás de Chile. Nutr. Hosp 27 (2012): 739-746. 
23. Ministerio de Sanidad y Consumo: Agencia Española de Seguridad Alimentaria. Estrategia NAOS. Estrategia para la Nutrición, Actividad Física y Prevención de la Obesidad. Madrid (2005).

24. Martínez-Gómez D, Ruíz JR, Ortega FB, et al. HELENA Study Group. Recommended levels of physical activity to avoid an excess of body fat in European adolescents. Am. J. Prev. Med 39 (2010): 203-211.

25. González-Jiménez E, Cañadas GR, Fernández-Castillo R, et al. Analysis of the life-style and dietary habits of a population of adolescents. Nutr. Hosp 28 (2013): 1937-1942.

26. Ortega Anta RM, López Sabaler AM. Nutritional concerns and specific problems at different stages of life. In Nutrition in adolescence and youth. Requejo AM and Ortega, RM (2002).

27. Rizo-Baeza MM, González-Brauer NG, Cortés E. Calidad de la dieta y estilos de vida en estudiantes de ciencias de la salud. Nutr. Hosp 29 (2014): 153-157.

28. Encuesta Estatal sobre uso de drogas en Enseñanzas Secundarias (ESTUDES) España 2012/2013. Ministerio de Sanidad, Servicios sociales e Igualdad. Secretaría de Estado de Servicios sociales e Igualdad. Madrid (2013).

Citation: Iglesias MT, Cuesta E. Comparative Study of Habits in Scholar Students before and During His University Studies in Spain. Journal of Environmental Science and Public Health 2 (2018): 24-35.

\footnotetext{
(C) (1) $\begin{aligned} & \text { This article is an open access article distributed under the terms and conditions of the } \\ & \text { Creative Commons Attribution (CC-BY) license } 4.0\end{aligned}$
} 